\title{
Historical and recent occurrence of epixylous moss Buxbaumia viridis in the Javorníky Mts. and the Vsetínské vrchy hills (Western Carpathians)
}

\author{
Vítězslav Plášek \& Eva Novozámská
}

\begin{abstract}
Historical and recent occurrence of epixylous moss Buxbaumia viridis in the Javorníky Mts. and the Vsetínské vrchy hills (Western Carpathians) - Čas. Slez. Muz. Opava(A), 60: 185-189, 2011.

Abstract: The epixylous moss Buxbaumia viridis (Moug. ex Lam. \& DC.) Brid. ex Moug. \& Nestl. is considered an endangered or vulnerable species in all countries in the Central Europe. In the Czech part of the Western Carpathians the species was recorded very occasionally in the twentieth century. In 2011 field monitoring of the species on historically known localities in Javorníky Mts. and the Vsetínské vrchy hills was carried out. As a result, six localities of $B$. viridis have been recorded in this region. Precise localization, number of and ecological data are given.

Key words: Bryophyta, Buxbaumia viridis, Javorníky Mts., Vsetínské vrchy hills, Western Carpathians, endangered species, ecology, Natura 2000
\end{abstract}

\section{Introduction}

Buxbaumia viridis (Moug. ex Lam. \& DC.) Brid. ex Moug. \& Nestl. is a highly specialized and atypical moss with reduced leaves arising from a protonemal mat and having a large distinctive capsule (Fig. 1e-i). The sporangia are persistent and produce extremely high numbers of unusually small spores -4.3 to 6.0 million spores sized ca. $10 \mu \mathrm{m}$ were reported by Wiklund (2002) or Plášek (2004). The species is very specific in its habitat requirements being restricted to decaying wood in wet, shaded places in woodland. It is widespread in the Western Carpathians but is considered as rare and threatened in most countries of Central Europe (e.g. Ochyra 1992; Kubinská et al. 2001; Kučera \& Váňa 2005) and is also included in Annex II of the EC Directive 92/43/EEC on conservation of natural habitats and of wild fauna and flora.

\section{Methods}

The field research in Javorníky Mts. and Vsetínské vrhcy hills was carried out during October 2011 by authors. A list of localities with occurrence of Buxbaumia viridis is given bellow. In addition, ecological data (e.g. environmental characteristics of localities, species identification of rotting wood, decaying wood stage, slope and exposure) and population data (number of capsules, their stage of ontogeny) were also collected.

Description of these variables is necessary for understanding the species requirements. A unique scale of wood decomposition divided in 8 classes was taken from Söderström (1988): 1. Wood hard, bark remaining intact. 2. Wood hard, bark broken up in patches but more than $50 \%$ remaining. 3. Wood hard, less than $50 \%$ bark remaining. 4. Wood has started to soften, without bark, texture smooth. 5 Wood soft, with small crevices and small pieces lost. 6. Wood fragments lost so the outline of the trunk is deformed. 7. The outer surface of the log is hard to define, possibly with a core of harder wood. 8. Completely soft without evidence of hard wood, outline indeterminable.

The bryophytes species names follow Check- and red list of bryophytes of the Czech Republic (Kučera \& Ván̆a 2005). Presented GPS coordinates correspond with WGS-84 (World Geodetic System 1984).

\section{HISTORICAL RECORDS}

The following list of localities consists of all historical and recent data on the occurrence of the species in the Javorníky Mts and the Vsetínské vrchy hills. Historical records are based upon literature data. A list of localities is arranged by their location from north to south.

- Valley of Kobylská stream: leg. Jedlička 1951 - BRNM (Soldán 1992); not. Hradílek 2002; not. Plášek 2008

- Loc. Hrubá Brodská, Popradný forest: leg. Jedlička 1951 - BRNM (Soldán 1992); not. Hradílek 2002; not. Plášek 2008 
- Vsacký Cáb hill: leg. Pospíšil 1951 - BRNM (Soldán 1992)

- Tísňavy valley: leg. Pospíśil 1951 - BRNM (Soldán 1992)

- Velké Karlovice town, loc. Kasárna: leg. Pospíšil 1951 - BRNM (Soldán 1992); not. Hradílek 2003

- Valley of Príschlop stream, loc. Noclehy: leg. Pospíšil 1949 - BRNM (Soldán 1992); not. Hradílek 2003

- Karolinka town, valley of Velká Stanovnica: leg. Pospíšil 1949 - BRNM (Berka 2010); not. Hradílek 2002

- Halenkov village, Čerňavská Kyčera Mt.: leg. Dvořáková 1998 - PRC (unpublished); not. Plášek 2008

- Valley of Senice stream: leg. Pospíšil 1951 - BRNM, OLM (Soldán 1992); not. Hradilek 2002

\section{RECENT RECORDS (2011)}

An occurrence of the moss was confirmed at six localities and in four of them more than one population was recorded.

Loc. 1

2.5 km NNW of Karolinka town - part Kobylská, in a valley of Kobylská stream, beech forest (with merging of Acer pseudoplatanus and Picea abies), 587m a.s.l., GPS: $49^{\circ} 22 ' 32.9^{\prime \prime} \mathrm{N}, 1^{\circ} 12^{\prime} 52.0^{\prime \prime} \mathrm{E}$

- recorded 4 young capsules and 1 expired seta.

- ecology: decaying spruce log, length $500 \mathrm{~cm}$, width $20 \mathrm{~cm}$, decaying stage: 4, exposition: W, inclination: $0^{\circ}$

- associated species (to a distance max. $5 \mathrm{~cm}$ ): Herzogiella seligeri, Chiloscyphus profundus, Rhizomnium punctatum

Loc. 2

2.5 km NW of Nový Hrozenkov town - part Brodské, loc. Hrubá Brodská, valley of Brodská stream, approximately 50 -years old spruce forest

Microlocality a): $583 \mathrm{~m}$ a.s.1., GPS: $49^{\circ} 22^{\prime} 05.8^{\prime \prime} \mathrm{N}, 18^{\circ} 10^{\prime} 52.8^{\prime \prime} \mathrm{E}$

- recorded 2 young capsules

- rotten spruce stump, height $40 \mathrm{~cm}$, width $45 \mathrm{~cm}$, decaying stage 7, exposition: SW, inclination: $5^{\circ}$

- associated species (to a distance max. $5 \mathrm{~cm}$ ): Herzogiella seligeri, Rhizomnium punctatum.

Microlocality b): 592 m a.s.1., GPS: 49²2'05.1" N, 18¹0'52.1" E

- recorded 3 young capsules

- rotten spruce stump, height $55 \mathrm{~cm}$, width $50 \mathrm{~cm}$, decaying stage 7, exposition: W, inclination: $20^{\circ}$

- associated species (to a distance max. $5 \mathrm{~cm}$ ): Herzogiella seligeri.

Loc. 3

$3.5 \mathrm{~km}$ ESE of Malé Karlovice village, valley of Př́́schlopský potok stream, loc. Noclehy, full-grown spruce forest (with merging of Fagus sylvatica)

Microlocality a): $774 \mathrm{~m}$ a.s.1., GPS: $49^{\circ} 20^{\prime} 07.0^{\prime \prime} \mathrm{N}, 18^{\circ} 22^{\prime} 31.6^{\prime \prime} \mathrm{E}$

- recorded 13 young capsules, 2 matured capsules and 1 expired seta.

- decaying beech log length $170 \mathrm{~cm}$, width $40 \mathrm{~cm}$, decaing stage 6 , exposition: NE, inclination: $10^{\circ}$

- associated species (to a distance max. $5 \mathrm{~cm}$ ): Herzogiella seligeri, Chiloscyphus profundus

Microlocality b): $773 \mathrm{~m}$ a.s.1., GPS: 49²0'07.0" N, 18²2'31.6" E

- recorded 9 young capsules

- decaying beech log, length $100 \mathrm{~cm}$, width $40 \mathrm{~cm}$, decaying stage 5, exposition W, inclination: $10^{\circ}$

- associated species (to a distance max. $5 \mathrm{~cm}$ ): Herzogiella seligeri

Loc. 4

$6 \mathrm{~km}$ ESE of Velké Karlovice village, loc. Kasárna, full-grown spruce forest along Czech-Slovak border line

Microlocality a): $833 \mathrm{~m}$ a.s.1., GPS: $49^{\circ} 19^{\prime} 36.0^{\prime \prime} \mathrm{N}, 18^{\circ} 22^{\prime} 19.9^{\prime \prime} \mathrm{E}$

- recorded 2 spilled capsules and 1 expired seta

- decaying spruce log, length $250 \mathrm{~cm}$, width $25 \mathrm{~cm}$, decaying stage 5, exposition: NE, inclination: $0^{\circ}$

- associated species (to a distance max. $5 \mathrm{~cm}$ ): Herzogiella seligeri, Dicranum scoparium

Microlocality b): 809 m a.s.1., GPS: 49¹9'35.7" N, 18²2'19.2" E

- recorded 1 young capsules and 2 expired setae

- decaying spruce log, length $130 \mathrm{~cm}$, width $10 \mathrm{~cm}$, decaying stage 6 , exposition: SE, inclination: $15^{\circ}$

- associated species (to a distance max. $5 \mathrm{~cm}$ ): Herzogiella seligeri 


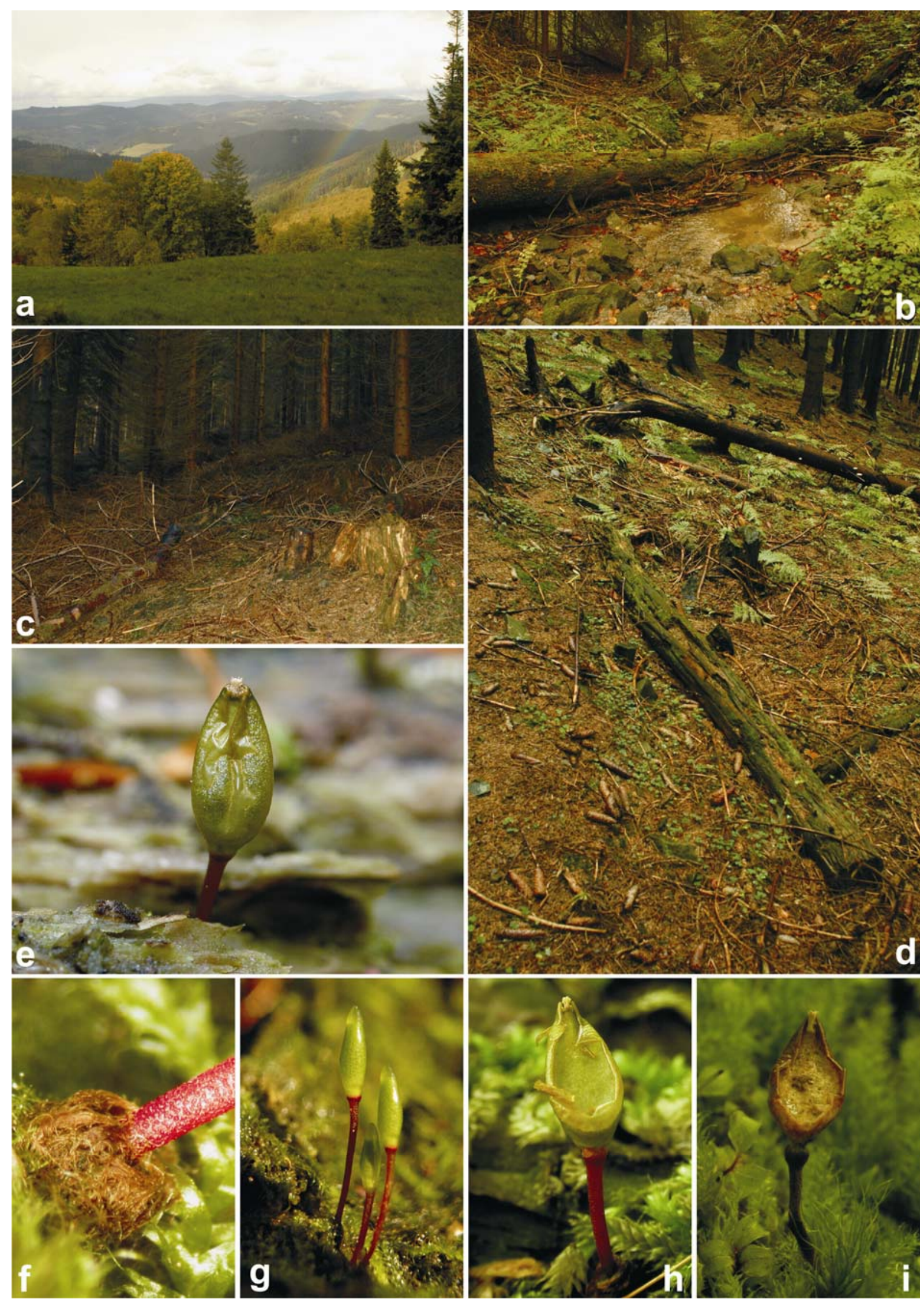

Fig. 1: a - a view on the Javorníky Mts. from the Javorníček Mt.; b-d - diverse types of habitats where the moss was recently recorded; e, $\mathbf{g}-\mathbf{i}$ - capsules of Buxbaumia viridis in different stage of ontogeny; $\mathbf{f}$ - typical reduced leaves of the moss plant and arising seta. 
Loc. 5

2 km SE of Halenkov village, valley of Provazný potok stream, full-grown spruce forest

Microlocality a): $601 \mathrm{~m}$ a.s.1., GPS: $49^{\circ} 18^{\prime} 14.4^{\prime \prime} \mathrm{N}, 18^{\circ} 10^{\prime} 43.6^{\prime \prime} \mathrm{E}$

- recorded 1 matured capsuled and 2 young capsules

- cutting surface of a spruce stump, height $30 \mathrm{~cm}$, width $20 \mathrm{~cm}$, decaying stage 4, exposition: N, inclination: $0^{\circ}$

- associated species (to a distance max. $5 \mathrm{~cm}$ ): Dicranum scoparium, Herzogiella seligeri, Hypnum cupressiforme, Chiloscyphus profundus, Rhizomnium punctatum.

Microlocality b): 606 m a.s.l., GPS: 49²18'13.8" N, 18¹0'42.8" E

- recorded 2 matured capsules and 2 young capsules

- decaying spruce stump, height $45 \mathrm{~cm}$, width $50 \mathrm{~cm}$, decaying stage 7, exposition: N, inclination: $20^{\circ}$

- associated species (to a distance max. $5 \mathrm{~cm}$ ): Herzogiella seligeri

Microlocality c): $606 \mathrm{~m}$ a.s.1., GPS: $49^{\circ} 18^{\prime} 12.6^{\prime \prime} \mathrm{N}, 18^{\circ} 10^{\prime} 43.0^{\prime \prime} \mathrm{E}$

- recorded 2 matured capsules

- rotten spruce stump, height $50 \mathrm{~cm}$, width $55 \mathrm{~cm}$, decaying stage 7, exposition: S, inclination: $10^{\circ}$

- associated species (to a distance max. $5 \mathrm{~cm}$ ): Herzogiella seligeri.

Loc. 6

$1.8 \mathrm{~km} \mathbf{N}$ of Valašská Senice village, valley of Senice stream, mixed forest (Fagus sylvatica with Picea abies), 731 m a.s.l., GPS: $4^{\circ} 15^{\prime} 27.4^{\prime \prime} \mathrm{N}, 1^{\circ} 08^{\prime} 53.7^{\prime \prime} \mathrm{E}$

- recorded 64 young capsules and 2 expired setae

- rotten spruce log (lying across a brook), length $600 \mathrm{~cm}$, width $35 \mathrm{~cm}$, decaying stage 4, exposition: S, inclination: $0-45^{\circ}$

- associated species (to a distance max. $5 \mathrm{~cm}$ ): Herzogiella seligeri, Chiloscyphus profundus, Jungermannia leiantha, Rhizomnium punctatum, Sanionia uncinata

\section{Conclusions}

Forests in the Czech part of the Western Carpathians, as elsewhere in these mountains, are dominated by conifers and beech and this is why Buxbaumia viridis occurs there primarily on the decaying wood of spruce (Picea abies) and rarely on beech (Fagus sylvatica). The moss prefers rotten logs or stumps in spruce or mixed forest, usually growing in valleys of streams. It is easily recorded only upon the production of sporophytes, thus preventing the collection of all biological and population-ecological data directly in the field, because one cannot detect the gametophyte's phase. Therefore most of the data collecting had to be based solely on observation of the capsules.

Screening of the capsules produced on different slopes showed that the species prefers the northern, western and/or southern slopes of rotten logs or stumps. Inclination was most often recorded as $0-10^{\circ}$.

Most of the recorded localities range in altitude from 600 to $750 \mathrm{~m}$. The lowest occurrence of the species was recorded at $583 \mathrm{~m}$ and the highest at $833 \mathrm{~m}$.

During the recent field survey in the study area, Buxbaumia viridis was found on 6 from 9 historically known localities. With regard to the habitat conditions seem to be well, the moss should not be endangered there in future.

Acknowledgements: Authors would like to thank the Agency for Nature Conservation and Landscape Protection of the Czech Republic (AOPK ČR) for financially supporting the research and accessing of their own biological data. The contribution of Vítězslav Plášek has been in connection with the project Institute of Environmental Technologies, reg. no. CZ.1.05/2.1.00/03.0100 supported by the Research and Development for Innovations Operational Program, financed by Structural Funds of the Europe Union and the state budget of the Czech Republic.

\section{References}

Berka T. (2010): Výskyt a rozšíření šikouška zeleného (Buxbaumia viridis) na Zlínsku. In: Západné Karpaty spoločná hranica. Sborník prííspěvků z II. Mezinárodního sympózia přírodovědců Trenčianského kraja a Zlínského kraje, 9. - 11. VI. 2010, pp. 20-22. 
Kubinská A., Janovicová K. \& Šoltés, R. (2001): Červený zoznam machorastov Slovenska [Red List of Bryophytes of Slovakia]. - Ochrana Prírody, 20 (Supplement): 31-43.

Kučera J. \& Váňa J. (2005): Seznam a červený seznam mechorostů České republiky (2005). - Př́roda, Praha, 23: $1-104$.

Ochyra R. (1992): Czerwona lista mchów zagrożonych w Polsce. [Red list of threatened mosses in Poland]. In Zarzycki K., Wojewoda W. \& Heinrich Z. (eds.), Lista roślin zagrożonych w Polsce. Wyd. 2 [List of threatened plants in Poland. 2nd ed.]. Instytut Botaniki im. W. Szafera Polskiej Akademii Nauk, Kraków: pp. 79-85.

Plášek V. (2004): The moss Buxbaumia viridis (Bryopsida, Buxbaumiaceae) in the Czech part of the Western Carpathians - distribution and ecology. In: Stebel A. \& Ochyra R. (eds) Bryological Studies in the Western Carpathians, Sorus, Poznań: pp. 37-44.

Soldán Z. (1992): Buxbaumia viridis - a candidate of "Red Lists" of bryophytes. - Bryonora, Praha, 9:40-44.

Söderström L. (1988): Sequence of bryophytes and lichens in relation to substrate variables of decaying coniferous wood in Northern Sweden. - Nordic J. Bot. 8: 89-97.

Wiklund, K. (2002): Substratum preference, spore output and temporal variation in sporophyte production of the epixylic moss Buxbaumia viridis. - Journal of Bryology, 24: 187-195.

Author's addresses: Vítězslav Plášek, Dept. of Biology \& Ecology, Faculty of Science, University of Ostrava, Chittussiho 10, CZ-710 00 Ostrava, Czech Republic, e-mail: vitezslav.plasek@osu.cz Eva Novozámská, Department of Botany, Charles University Prague, Benátská 2, CZ-128 01 Prague, Czech Republic; e-mail: eva.novozamska@gmail.com 